\title{
Morphological cells in the Ragusa littoral (Sicily, Italy)
}

\section{G. Anfuso, J. Á. Martínez-del-Pozo \& N. Rangel-Buitrago}

\section{Journal of Coastal Conservation}

Planning and Management

ISSN 1400-0350

Volume 17

Number 3

J Coast Conserv (2013) 17:369-377

DOI 10.1007/s11852-013-0233-8

\section{Journal of Coastal Conservation}

Planning and Management

Editor-in-Chief

David R. Green

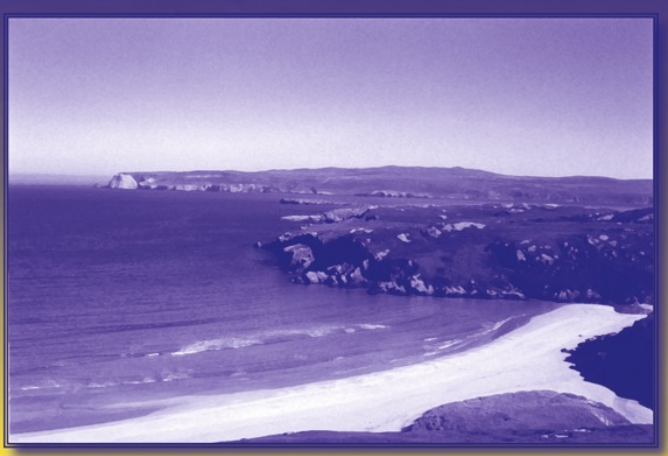

Springer

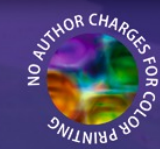

包 Springer 
Your article is protected by copyright and all rights are held exclusively by Springer Science +Business Media Dordrecht. This e-offprint is for personal use only and shall not be selfarchived in electronic repositories. If you wish to self-archive your article, please use the accepted manuscript version for posting on your own website. You may further deposit the accepted manuscript version in any repository, provided it is only made publicly available 12 months after official publication or later and provided acknowledgement is given to the original source of publication and a link is inserted to the published article on Springer's website. The link must be accompanied by the following text: "The final publication is available at link.springer.com". 


\title{
Morphological cells in the Ragusa littoral (Sicily, Italy)
}

\author{
G. Anfuso • J. Á. Martínez-del-Pozo • N. Rangel-Buitrago
}

Received: 3 December 2012 / Accepted: 3 January 2013 /Published online: 12 January 2013

(C) Springer Science+Business Media Dordrecht 2013

\begin{abstract}
Geomorphologic information, topographic maps (dated 1967), aerial photographs (dated 1999 and 2008), and spatial analysis procedures were used to investigate a $90 \mathrm{~km}$ long coastal sector in South Sicily (Italy). Information was obtained on coastal erosion/accretion areas, general sediment circulation pattern and littoral cell distribution. Human-made structures and natural headlands constituted important artificial limits dividing littoral in morphological cells. Ports and harbours were observed at Scoglitti, Punta Secca, Marina di Ragusa, Donnalucata and Pozzallo. Most of them worked as "transit" limits which interrupted predominant, eastward directed sedimentary transport, this way generating accretion in updrift (west) side of mentioned structures and erosion in downdrift (east) side. During the 1967-2008 period, about $62,000 \mathrm{~m}^{2}$ and $42,000 \mathrm{~m}^{2}$ of beach surface were respectively formed updrift of Scoglitti and Donnalucata ports. The construction of Pozzallo port gave rise to the formation of a "convergent" limit which favoured large accretion $\left(94,000 \mathrm{~m}^{2}\right)$ east of port structure. Most important natural structures were observed at Punta Zafaglione, P. Braccetto and Cava d'Aliga. The knowledge of littoral cell distribution acquires a great importance for appropriate management of coastal erosion processes which may be mitigated installing by-passing systems in ports and harbours and carrying out nourishment works in eroding areas, often located downdrift of ports and harbours (when these structures work as transit limits) and in central part of littoral cells (when these structures work as convergent limits).
\end{abstract}

Keywords Cell $\cdot$ Transport $\cdot$ Erosion $\cdot$ Sicily

G. Anfuso $(\bowtie) \cdot$ N. Rangel-Buitrago

Dpto. Ciencias de la Tierra, Facultad de Ciencias del Mar y

Ambientales, Universidad de Cádiz, Polígono Río San Pedro s/n,

11510 Puerto Real, Spain

e-mail: giorgio.anfuso@uca.es

J. Á. Martínez-del-Pozo

Instituto de Arqueología de Mérida - CSIC, Plaza de España, 15, 06800 Mérida, Badajoz, Spain

\section{Introduction}

Many geomorphologists and coastal managers have underlain the importance of budgetary approach to study littoral systems, i.e. the recognition, in qualitative or quantitative term, of sediment inputs, transport pathways and sediment outputs (Carter 1988; Bray 1997). The first step in this sense is the identification of coastal cells which are the result of the complex interaction between environmental parameters (especially waves characteristics and approaching directions) and coastal morphology (natural and man-made structures). Aforementioned interaction controls the distribution of erosion and accretion areas along littoral, as previously observed by several authors (Masselink and Pattiaratchi 2001; Cooper and Pethick 2005). Identification of littoral cells and sediment outputs and inputs within each littoral cell and the comprehension of transfer processes, which operate over a range of spatial and temporal scales, between adjacent cells, will become increasingly important in assessing regional and local impacts of sea-level rise and associated storms effects, and possible medium and long term mitigation strategies, including managed retreat and accommodation (Bray et al. 1995; Pilkey and Dixon 1996; Pethick 2001; Hansom 2001).

In this work, location and characteristics of main cell limits along a coastal sector located in Sicily (Italy) was investigated by considering the results of coastal evolution during the 1967-1999 period, also taking into account human and natural structures distribution and types. Obtained results constitute useful information to be employed by local government planning staff as a guide to the integrated coastal erosion management of the investigated littoral zone, and a study case which enlarges the general database and knowledge on littoral zone processes and behaviour.

\section{Study area}

Administratively, studied littoral belongs to the Ragusa Province, south of Sicily, Italy (Fig. 1). Coastal orientation 
varies from NW-SE in the northern sector, i.e. between the Dirillo River mouth and Point Secca promontory, to WNWESE for the central sector, i.e. Punta Secca - Cava d'Aliga, to E-W in the southern sector, i.e. Cava d'Aliga - Punta Castellazzo (Fig. 1). Nearshore areas present smooth, dissipative slopes and bathymetric contours are parallel to coastal line. Beaches, composed by sandy quartz-rich sediments, show low gradients and are backed by dune ridges and cliffs cut in sandstone, marl and limestone. Most cliffs are composed by hard cemented limestone and sandstone of the Miocene Ragusa Formation (Grasso 1997), i.e. between Casuzze and Marina di Ragusa, Cava d'Aliga and Sampieri and at Marina di Modica and Pozzallo, and consolidated Plio-Quaternary sandstone at P. Braccetto. All aforementioned cliffs, composed by hard rocks very resistant to waves attack, rain erosion and weathering processes, did not record retreat processes during last century (Anfuso and Martinez 2009).

An eroding bluff is formed at Camarina on Late Miocene clays (Tellaro Formation, Grasso 1997), and other cliffs, eroding at retreat rates that are too small to be characterized because of used methodology, are formed by Miocene consolidated marl at Pietre Nere, unconsolidated PlioQuaternary marl at Scoglitti and Caucana, and Quaternary unconsolidated marl and very fine calcareous sands and pebbles, at Irminio River mouth. No significant sedimentary inputs derive from cliff retreat because eroded sediments are generally too fine, being rapidly winnowed by waves and currents. Fluvial inputs are not significant because rivers are predominantly derived from chalk catchments; additionally, sediment supply was greatly restricted because of construction of dams and barrages in past decades (Anfuso and Martínez 2005).

Dealing with marine climate, the zone is microtidal (astronomical spring tidal range being $20 \mathrm{~cm}$ ) and principally affected by winds blowing from the third quadrant, winds from the second quadrant achieving greater importance in autumn and spring times. According to wave data recorded by the directional offshore buoy located at Mazzara del Vallo, in the Sicilian Channel, most frequent and severe

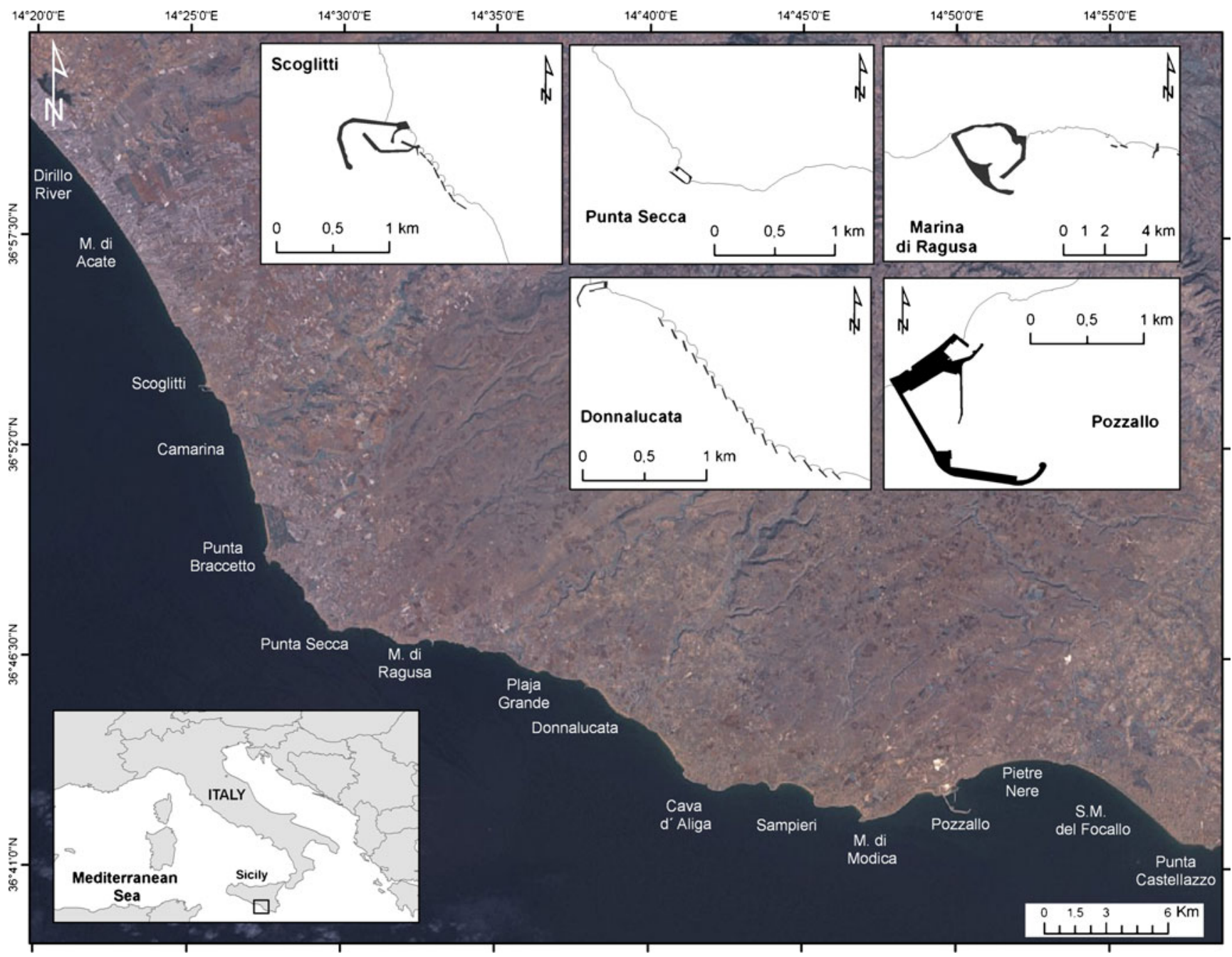

Fig. 1 Location map of studied area with detailed sketches of ports, harbours and protection structures 
storms approach from $\mathrm{W}$ and WNW with significant wave height values greater than $5.0 \mathrm{~m}$, less severe storms approach from $\mathrm{SE}$, with maximum significant values of $3.0 \mathrm{~m}$ (Fig. 2).

Due to coastal orientation, the northern sector is essentially affected by storms from west directions, while the central and southern sectors are stricken by storms approaching from east and west directions that give rise to important longshore currents, and from south approaching directions, that form a predominantly cross-shore transport. Consequently, main littoral drift in the area flows from west to east, which is reflected by a longshore decrease in sediment grain size, and an opposite transport is recorded in central and southern sectors (Martínez and Anfuso 2008).

\section{Methodology}

The analysis of coastal evolution has been carried out over a 32 year-period (medium-term, according to Crowell et al. 1993), by means of the "end point rate" method (Jiménez et al. 1997), using the 1967 topographic map (1:25,000 scale) and the 1999 geo-referenced orthophotographs (in colour, at $1: 12,500$ scale). Locally, an update of coastal evolution was carried out using the 2008 orthophotographs (in colour, at 1:12,500 scale). Following the methods described by Leatherman (1983) and Jiménez et al. (1997), these documents were scanned, geo-referenced and computer rectified to eliminate scale and distortion related problems (Lillesand and Kiefer 1987; Moore 2000). Erosion and accretion areas obtained comparing investigated coastlines were established by means of spatial analysis procedures provided by GIS tools.

As studied area is microtidal, shoreline was defined as the instantaneous water line position (Boak and Turner 2005); because it was not possible to reconstruct tidal condition at the moment the photograph was taken, it was assumed that the daily water line position is subject to a maximum uncertainty of $\pm 4 \mathrm{~m}$, taking into account the intertidal slope of the studied beaches (Dolan et al. 1980; Anonymus 2005). Wave height effects were not considered because no storm conditions were observed in any of the photographs. The effects of seasonal variation and influence of individual storms on shoreline evolution have limited importance because of the length of considered time span (Dolan et al. 1991). An additional positional shoreline error was determined with an accuracy of $\pm 8 \mathrm{~m}$ because of topographic map and photograph scales and spatial resolution limitations. Consequently, the total shoreline mapping error including

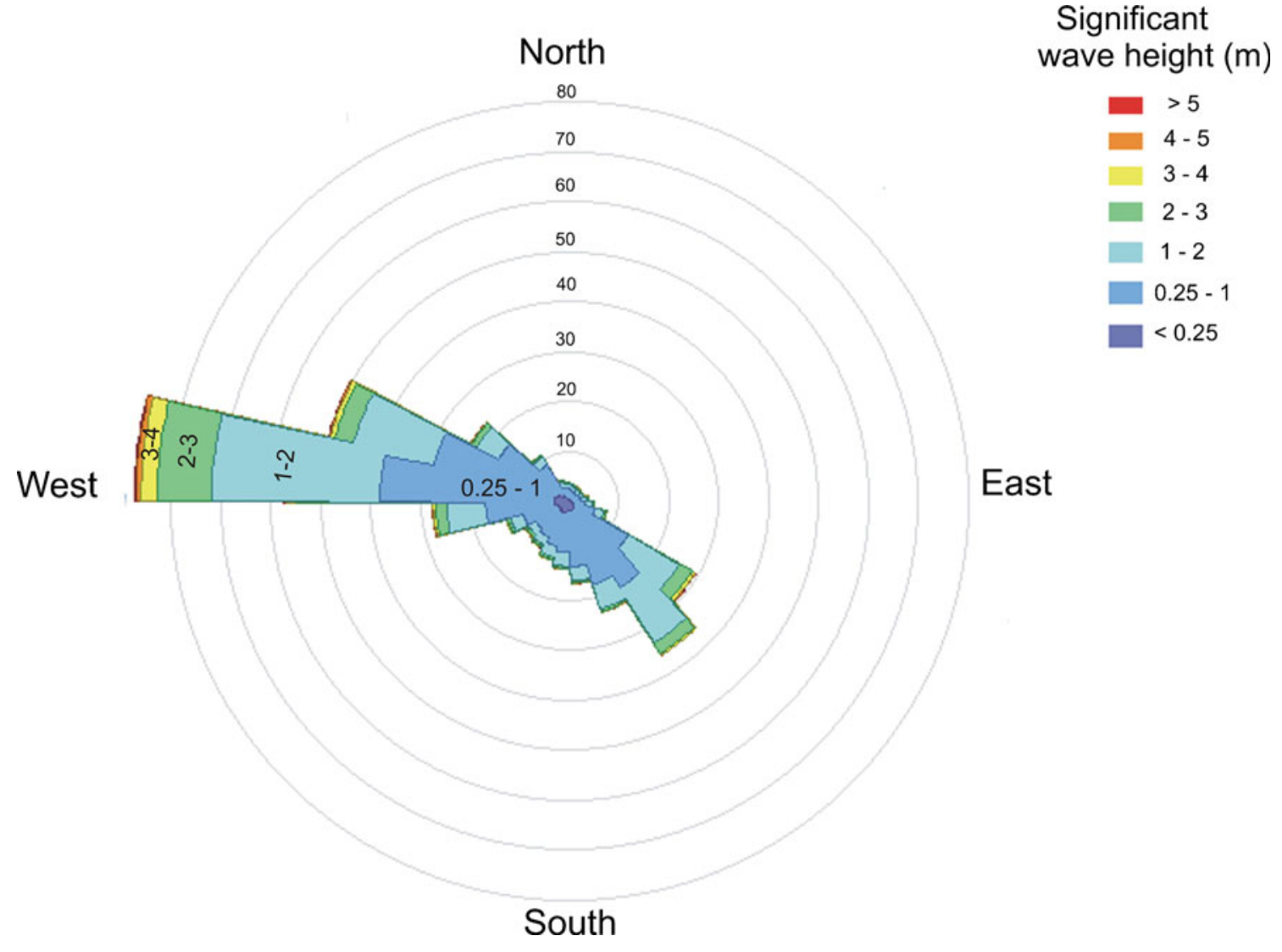

Fig. 2 Significant wave height recorded during the 1989-1999 period by the offshore buoy located at Mazzara del Vallo (Sicily Channel), over a water depth of about $20 \mathrm{~m}$. The buoy belongs to the Italian wave climate service 


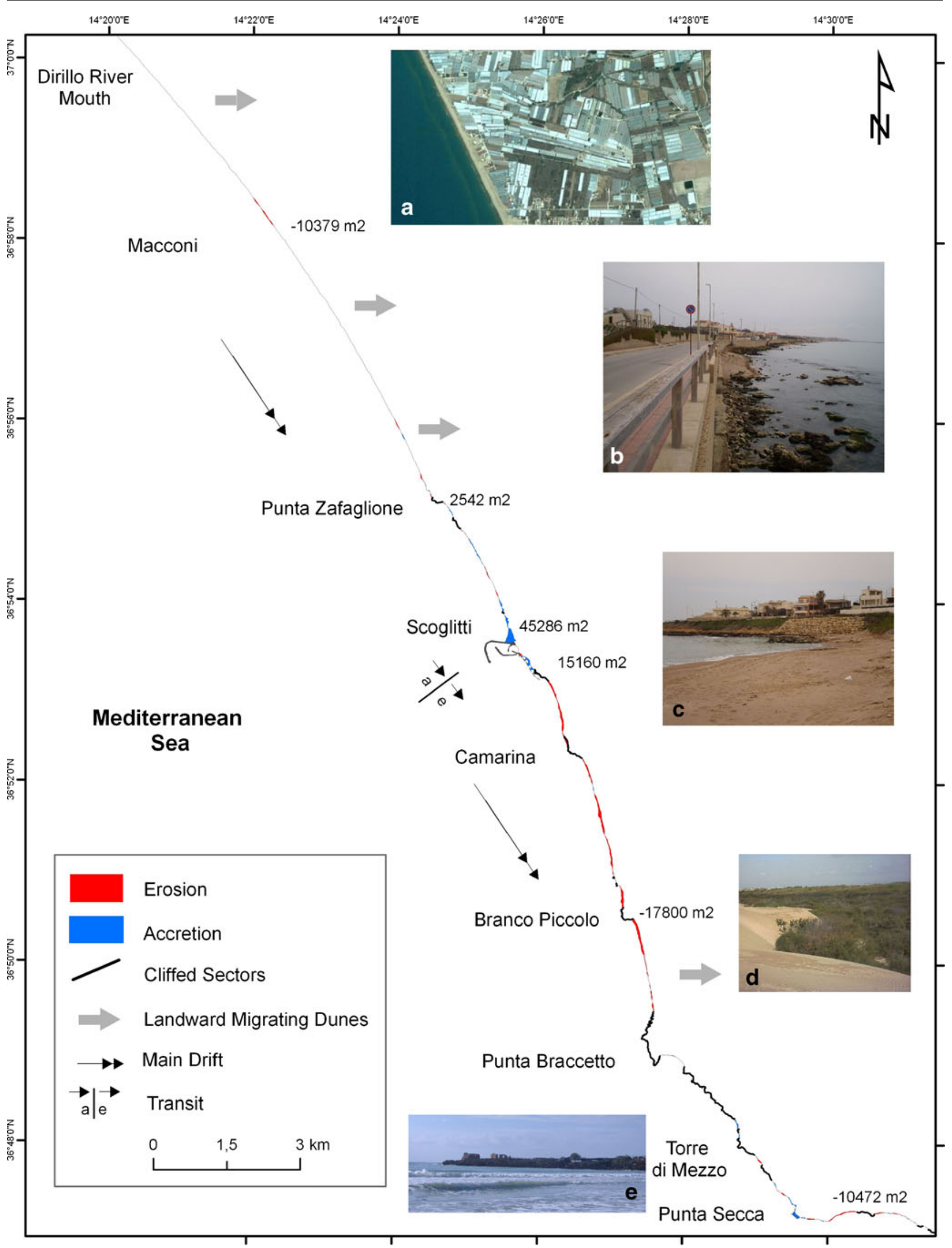


Fig. 3 Erosion/accretion areas for the 1967-1999 period and main cell limit characteristics for the Dirillo River mouth - P. Secca sector (northern sector). View of Macconi area heavily occupied by greenhouses emplaced on dune ridges (a); Erosion problems south of P. Zafaglione (b); Rip-rap revetment constructed downdrift of breakwaters at Scoglitti (c); Landward migrating dunes in the natural protected area at Punta Braccetto (d) and view of P. Braccetto headland (e)

uncertainty in shoreline position due to tidal condition, was assumed to be $\pm 12 \mathrm{~m}$ and beach surface variations (calculated along longshore sectors $200 \mathrm{~m}$ in length) lower than $2,400 \mathrm{~m}^{2}$, were not considered representative and were not depicted in presented figures.

Concerning littoral cells, they can be defined by morphological, sedimentological and/or hydrodynamic criteria (May and Tanner 1973; Lowry and Carter 1982; Carter 1988). In this work, morphological criteria were used and cell limits located in places of discontinuities in sediment transport direction (Bray et al. 1995). Limits were classified as "fixed", if presented a great temporal stability, and "free", if their position changed according to wave approaching characteristics (Carter 1988; Bray et al. 1995) and as "divergent" (when littoral drift divided in correspondence with limit), "convergent" (when opposite littoral drifts converged at limit) or "transit" (when accretion was recorded at one side and erosion at the other side of limit, Lowry and Carter 1982). Absolute limits were barriers to all sediments, whereas partial or permeable boundaries permitted bypassing. Concerning accreting or eroding zones close to cell limits, they were respectively named as "a" and "e". Last, by means of thorough field observations, information was gathered on sediment sinking areas, i.e. areas of dune formation and landward migration.

\section{Results}

The investigated littoral works as a unique large physiographic unit divided in several cells of different dimensions, limited by fixed, natural and artificial limits. In detail, in the studied area, sediments broadly move from west to east because of longshore transport which impinges on natural and human-made coastal structures, giving rise to the accreting/eroding areas depicted in Figs. 3, 4, and 5. In following lines, cell distribution was described from west to east to achieve a better understanding of very local coastal behaviour and effects of natural and human-made structures.

In the northern sector, a lengthy cell extends from Gela port (out beyond the studied zone) to Scoglitti port (Fig. 3). Main longshore drift flows south-eastward accumulating sediments updrift (north) of Scoglitti port which constitutes an almost absolute, transit limit. In the 1967-1999 period, about $45,000 \mathrm{~m}^{2}$ of new beach were formed and further increase $\left(16,760 \mathrm{~m}^{2}\right)$ was observed in the 1999-2008 period
(Fig. 3). Accumulated sediments are not removed by second and third quadrants approaching waves and associated currents. Six breakwaters were progressively constructed to solve downdrift (south) erosion problems which now threats backing coastal road protected by rip-rap revetment (Fig. 3c). In the central part of the investigated cell, along P. Zafaglione - Scoglitti sector, erosion problems were increasing in past years generating beach loss, rock falls in backing cliff and damages to littoral road (Fig. 3b).

The littoral cell between Scoglitti and P. Secca is made up of sub-cells formed by linear coastal sectors and pocket beaches of different dimensions limited by headlands and cliffed sectors, the most important being P. Braccetto and Torre di Mezzo (Fig. 3e). Aforementioned limits generally work as fixed, transit and permeable limits which basically allow sediment bypass from NW to SE according to predominant littoral drift direction.

In the coastal sector presented in Fig. 3, foredunes and landward migrating dunes are located along the Dirillo River mouth-P. Zafaglione sector and at Punta Braccetto (Fig. 3a and d).

Punta Secca harbour and Marina di Ragusa port are fixed, convergent limits (Fig. 4). The former is a permeable, bidirectional limit which is easily bypassed by sediments principally flowing from $\mathrm{W}$ to $\mathrm{E}$, although approximately $4,000 \mathrm{~m}^{3}$ of sediments are yearly impounded at P. Secca. Marina di Ragusa port, inaugurated July 2009, is stopping westward drift and sediments eroded in central part of this cell (i.e. at Caucana and Casuzze, Fig. 4a) are accumulating in deep water areas close to western dock. Probably, minor amount of such sediments is redistributed back to the central part of the cell by westward directed drift. On the eastern side of M. di Ragusa port, an artificial large beach, protected by two submerged breakwaters, was created with sediments dredged during port construction (Fig. 4b). Dredged sediments, which came from Caucana and Casuzze areas, were this way subtracted to their original cell and transferred to the adjacent morphological cell located east of M. di Ragusa.

Adjacent littoral cell is enclosed between Marina di Ragusa port and Donnalucata harbour (Fig. 4). The second gave rise to large accretion updrift (west, almost $42,000 \mathrm{~m}^{2}$ ) and erosion downdrift (east), this way constituting an absolute, transit limit. Port entrance, south-westward oriented, acts as a sedimentary trap for westward directed transport. Within the cell, volumes of sediments were accumulated beyond two, $70 \mathrm{~m}$ large, breakwaters at Marina di Ragusa and $240 \mathrm{~m}$ large one at Plaja Grande. In detail, protective structures at M. di Ragusa gave rise to beach surface accretion (about 11,500 $\mathrm{m}^{2}$ during the 1967-1999 period), and the breakwater at Plaja Grande gave rise to an huge sedimentation (about 60,000 $\mathrm{m}^{2}$ ) during the 1967-1977 period (Martínez and Anfuso 2008), with $5,000 \mathrm{~m}^{2}$ of new beach 


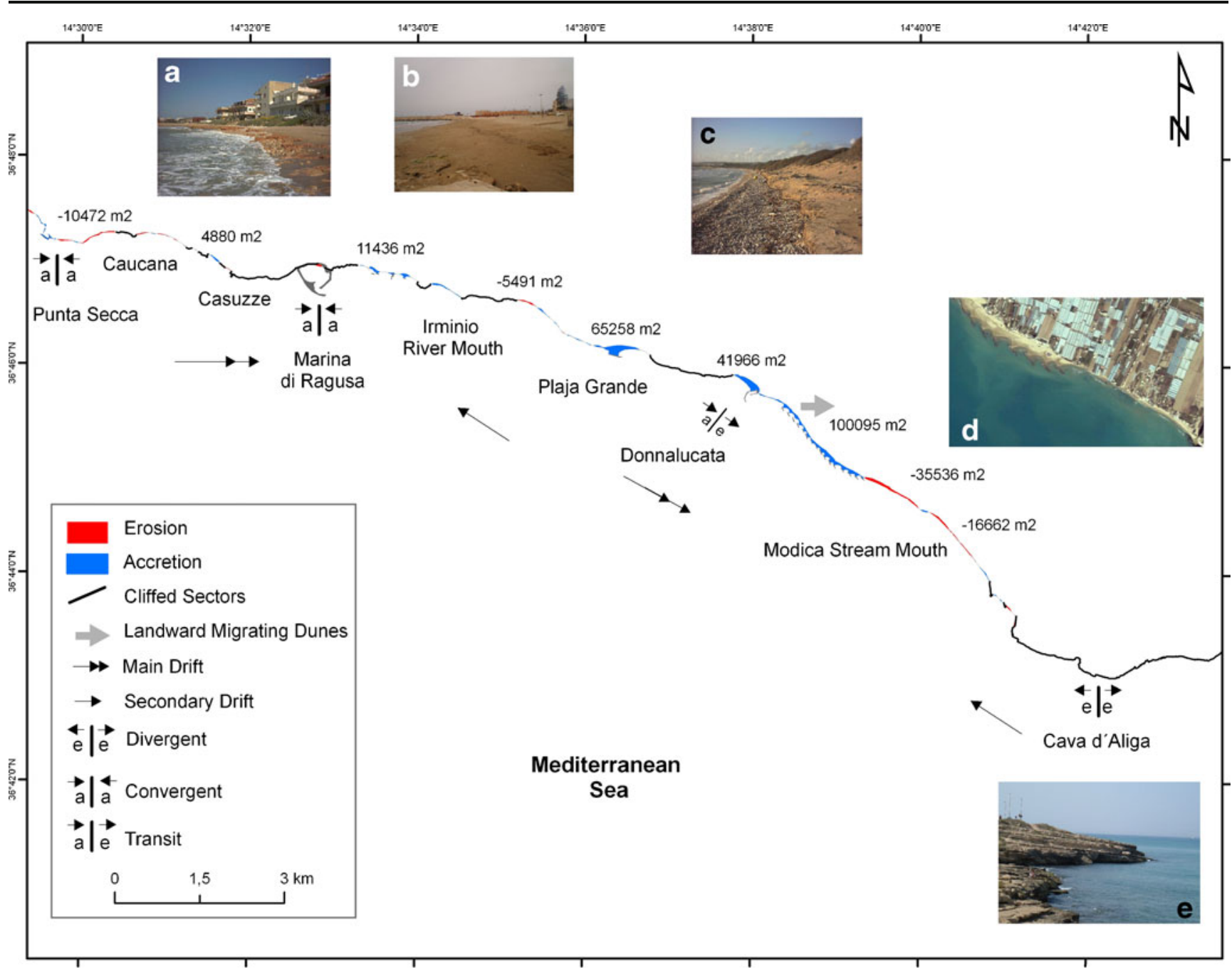

Fig. 4 Erosion/accretion areas for the 1967-1999 period and main cell limit characteristics for the P. Secca - Cava d'Aliga sector (central sector). Erosion at Caucana (a); Artificial beach east of M. di Ragusa port built up with dredged sediments (b); Ancient deposits constituted by calcareous gravels and blocks outcropping at the natural protected area at the Irminio River mouth (c); Donnalucata: accretion beyond breakwaters and downdrift beach narrowing because of erosion processes (d) and view of Cava d'Aliga headland (e) formed in the 1977-1999 period. Aforementioned breakwaters worked during several years as convergent and almost absolute limits. Presently, mentioned breakwaters form a swash-aligned shoreline impounding great quantities of sediments lost to the system. Erosion was consequently generated in central part of the cell, namely at Irminio River mouth, where sand was winnowed and ancient deposits outcrop (Fig. 4c).

Nearby, eastward littoral cell is enclosed between Donnalucata harbour and Cava d'Aliga headland (Fig. 4e) which works as divergent limit. Distribution of erosion/accretion areas within this cell is strongly conditioned by 16 breakwaters (Fig. 1) progressively constructed downdrift of Donnalucata harbour, according to the "domino" effect (Cooper et al. 2009). Presently, summer houses located downdrift of mentioned structures are protected by rip-rap revetments (Fig. 4d). Surplus of sediments, accumulated in correspondence with breakwaters east of Donnalucata, gave rise to formation of landward migrating foredunes menacing at places summer houses and invading agricultural devoted areas.

The littoral between Cava d'Aliga and Pozzallo port contains several cells formed by pocket beaches (i.e. at Sampieri, M. di Modica and Maganuco), delimited by natural headlands working as partial, transit limits (Fig. 5). At these places, during past decades, important sediment supplies from nearshore favoured beach accretion, dune formation and landward migration because of westerly winds (Fig. 5a).

The easternmost littoral cell is enclosed between Pozzallo port and P. Castellazzo headland and contains several subcells, i.e. the small pocket beach at Pozzallo and two large beaches, the eastern one located between Pozzallo village and Pietre Nere headland and the western one located 


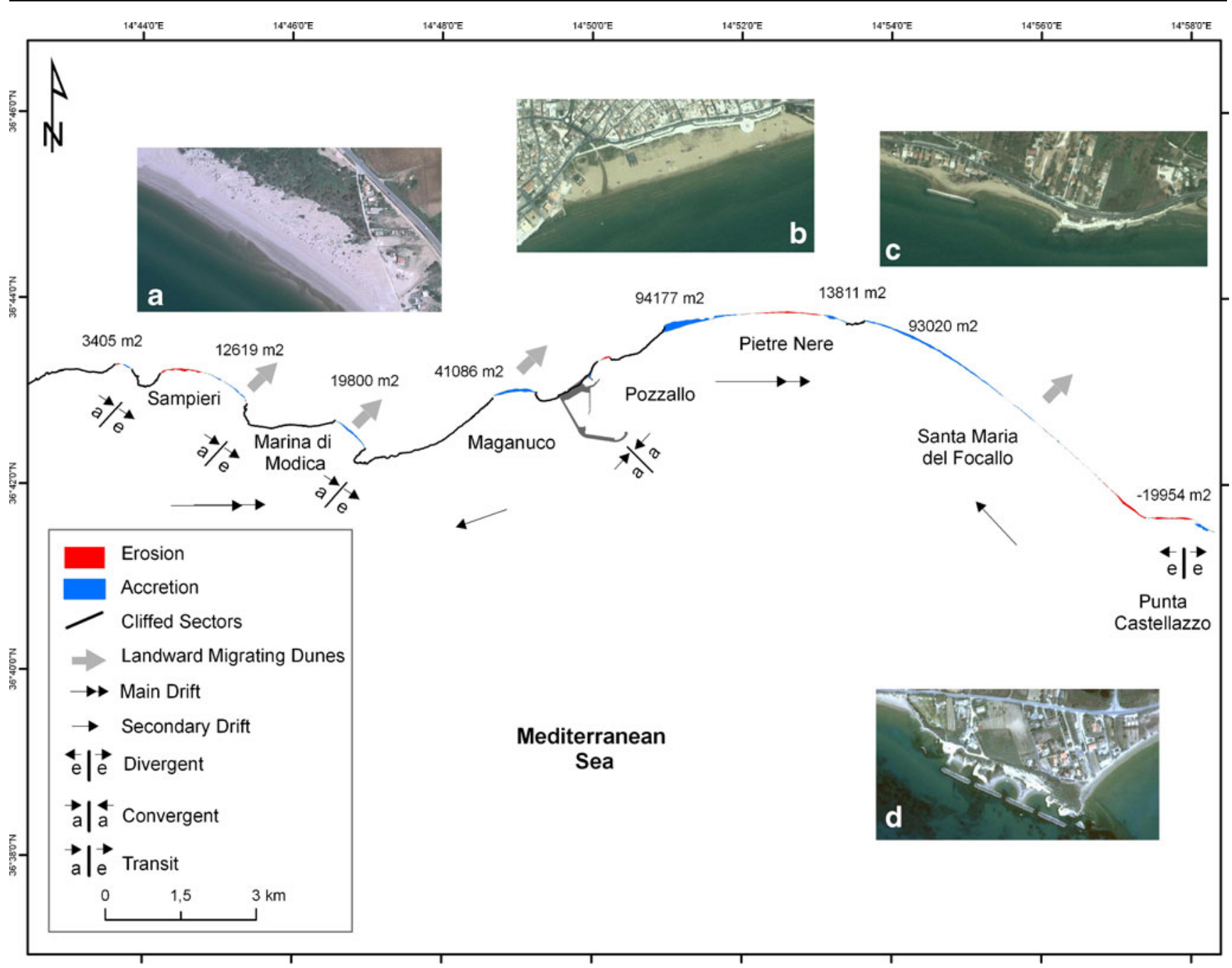

Fig. 5 Erosion/accretion areas for the 1967-1999 period and main cell limit characteristics for the Cava d'Aliga - P. Castellazzo sector (southern sector). Well developed, landward migrating dunes at

between the aforementioned headland and P. Castellazzo. Pozzallo port gave rise to the formation of an absolute, convergent limit, with accretion processes especially evident in the eastern side where huge volumes of sediments were impounded in nearshore zone creating infilling problems, and in Pozzallo beach, producing about $95,000 \mathrm{~m}^{2}$ of beach accretion mostly recorded in the 1987-1999 period after the modification and enlargement of port structure. Tourism developments, i.e. bars, restaurants, beach facilities and a promenade were constructed on recently formed beach (Fig. 5b). P. Castellazzo headland, partially protected by 4 breakwaters that induced $4,000 \mathrm{~m}^{2}$ of beach accretion during the 1987-1999 period, acts as divergent limit (Fig. 5d). Quantities of sediments were impounded at Pietre Nere (Fig. 5c) where a $150 \mathrm{~m}$ long breakwater worked as a convergent limit forming almost $14,000 \mathrm{~m}^{2}$ of beach surface during the 1967-1999 period, most important accretion $\left(8,600 \mathrm{~m}^{2}\right)$ being observed during the $1977-1987$ decade.
Sampieri (a); Restaurants, bars and a promenade (in white) constructed on the accreted beach east of Pozzallo (b); The breakwater and Pietre Nere headland (c) and breakwaters at P. Castellazzo (d)

Beach plan form pivoting because of westward directed transport, is evident in the observed sub-cells limited by partial, transit fixed limits constituted by cliffed sectors at Pietre Nere and Pozzallo (Fig. 5c), main erosion processes being observed at Santa Maria del Focallo through beach surface reduction and damage of littoral road.

\section{Discussion}

In the investigated littoral, effects of coastal embaymentisation on beach plan form and surf zone circulation were quite evident because waves produced longshore movement of sand with erosion in updrift cell side and accumulation in downdrift side. This process was reflected by a pivoting in beach plan form as observed in well-defined pocket beaches limited by major headlands (southern sector, Fig. 5), or in large littoral cells delimited by natural and man-made 
structures (Figs. 3 and 4) that formed fixed limits in the sense of Bray et al. (1995).

In detail, natural and man-made structures affected littoral drift depending on their exact location, shape and dimensions, and wave approaching characteristics (Bray et al. 1995). Main headlands and cliffed coastal sectors constituted limits of different importance which allowed periodic unidirectional or bidirectional transport that took place along narrow zones parallel to shoreline, approximately extending to $10 \mathrm{~m}$ water depth and depending on wave conditions and bottom morphology, and as bed load onto longshore bars (Anfuso and Martínez 2005).

Most important, human-made, fixed limits were represented by Scoglitti, Marina di Ragusa and Pozzallo ports and Donnalucata harbour and, secondarily, by Punta Secca harbour. They acquired much more importance respect to natural limits, this is opposite to the findings of Bray (1997) and Pranzini (2001) which observed as natural structures, because of their significant dimensions, achieved great importance in coastal embaymentisation in South England and Tuscany littoral (Italy).

Erosion in central part of investigated cells represented a common tendency counteracted by construction of hard protective structures which constituted fixed limits. Hence, breakwaters favoured accretion processes at Scoglitti, Marina di Ragusa, Plaja Grande, Donnalucata, Pietre Nere and Punta Castellazzo, but shifted erosion downdrift as observed in other coastal sectors by Jayappa et al. (2003), Zviely and Klein (2003), Phillips (2007) and Rodríguez and Dean (2009), and gave rise to a swash aligned shoreline.

Obtained results clearly highlight as coastal compartmentalization acquires a great importance for comprehension and solution of erosion problems in the investigated littoral. In fact, important erosion recorded in past decades was essentially related to construction of ports and harbours that constitute absolute limits to coastal transport. Important quantities of sediments were accumulated updrift of ports generating erosion problems in downdrift areas. Further, port and harbour record infilling processes because their entrances are located within the surf zone. In order to solve port infilling problems, docks were enlarged several times exacerbating downdrift erosion. Marina di Ragusa port, which was inaugurated July 2009, is already recording infilling problems. The northern dock of Scoglitti port, which was enlarged several times since the 1960 s, was enlarged once more in 2008, with a cost of 10 millions of Euros. Surprisingly, bypass systems have not been implemented in any case and hard versus soft solution was preferred when destruction of property was imminent, without any adequate plan or consideration of long term side-effects. Recently, soft solution is becoming popular: nourishment works were carried out at Caucana in 2004 and artificial fills are being projected for central eroding areas of littoral cells, namely at P. Zafaglione-Scoglitti sector, Casuzze and Caucana areas, Modica Stream mouth and S.M. del Focallo beach. Last, a locally important issue is dune formation and landward migration. As a result quantities of sediments are transported inland and lost to the system. Fences or vegetal stabilization should be applied to stop landward dune migration and accumulated sediments could be used to nourish eroding areas.

Concerning coastal erosion management policies in Italy, responsibilities are vertically distributed among National, Regional, Provincial and Municipal Administrations. In Sicily there is not a general management plan at regional or even provincial scale; in 2009, competences on coastal protection were transferred from provinces to municipalities which are not technically prepared and lack of a global view on erosion processes that overpass administrative borders. In fact, updrift of main ports, i.e., at Scoglitti, Donnalucata and Pozzallo, beach enlargement favoured the development of restaurants, recreational activities, etc., enhancing in this way local economy; the opposite being true for eroding areas, often located in the adjacent municipality. This was the case of Pozzallo port: sediments eroded at Santa Maria del Focallo beach (belonging to Ispica Municipality) were impounded in Pozzallo Municipality, east of the port. Erosion processes at Santa Maria del Focallo beach produced important economic losses to the Ispica Municipality because: i) the decrease of beach width determined the diminution of tourism attractiveness of the area (with an associated decline of summer house renting market) and, ii) damages to a littoral road and associated costs for reconstruction and emplacement of protection structures.

\section{Conclusions}

The studied littoral is divided by (mainly) human-made and (secondarily) natural structures in seven main cells of different dimensions and characteristics. Distribution of accreting/eroding areas along the investigated littoral resulted from the interaction of main eastward directed longshore transport (and an opposite one) with natural and human-made coastal structures. Ports worked as transit or convergent limits, i.e. accretion took place at one or both side of limit. Erosion areas were located immediately downdrift of ports, when such structures worked as transit limits, or in central part of littoral cells, when ports worked as convergent limits and opposite transport achieved a certain importance. Further, ports recorded periodic infilling processes but bypass systems were never implemented and their docks were elongated several times since their construction, this supposing a great amount of money and increase of updrift accretion and related downdrift erosion processes, counteracted by construction of hard protective structures (essentially breakwaters) which locally 
favoured sedimentation but shifted erosion downdrift (domino effect).

Hence, huge volumes of sediments were impounded close to Scoglitti, Donnalucata and Pozzallo ports and in correspondence with protection structures at several localities. In many cases very large beaches were formed and recreational activities emplaced (bars, restaurants, etc.) enhancing local economy, the opposite being true for eroding areas.

Concerning coastal erosion management, since 2009, competences were transferred to local municipalities and several nourishment projects are planned for central eroding area of different cells but there is not a general management plan which should take into account coastal compartmentalization and implement sediment bypass systems.

Acknowledgments This work was partially carried out at the CACYTMAR Research Centre (Junta de Andalucía - Universidad de Cádiz) and it is a contribution to the Andalusia PAI Research Group RNM-328. Thanks go to Morris Floridia for field assistance.

\section{References}

Anfuso G, Martínez JA (2005) Towards management of coastal erosion problems and human structure impacts using GIS tools: case study in Ragusa Province, Southern Sicily, Italy. Environ Geol 48:646-659

Anfuso G, Martinez JA (2009) Assessment of coastal vulnerability through the use of GIS tools in South Sicily (Italy). Environ Manag 43:533-545

Anonymus (2005) Monitoraggio volumetrico, sedimentologico e morfometrico dell'intero litorale ibleo. Final Report. Provincia Regionale di Ragusa. $57 \mathrm{p}$

Boak E, Turner I (2005) Shoreline definition and detection: a review. J Coast Res 21(4):688-703

Bray M (1997) Episodic shingle supply and the modified development of Chesil Beach, England. J Coast Res 13(4):1035-1049

Bray M, Carter D, Hooke J (1995) Littoral cell definition and budgets for central southern England. J Coast Res 11(2):381-400

Carter RWG (1988) Coastal environments. Academic Press 617 pp

Cooper N, Pethick J (2005) Sediment budget approach to addressing coastal erosion problems in St. Ouen's Bay, Jersey, Channel Island. J Coast Res 21(1):112-122
Cooper A, Anfuso G, Del Río L (2009) Bad beach Management: European perspectives. Geol Soc Am Spec Pap 460:167-179

Crowell M, Leatherman SP, Buckley M (1993) Shore-line change rate analysis: long term versus short term data. Shore Beach 61(2):13-20

Dolan R, Hayden B, May P, Suzette R (1980) The reliability of shoreline change measurements from aerial photographs. Shore Beach 48:22-29

Dolan R, Fester MS, Holme SJ (1991) Temporal analysis of shoreline recession and accretion. J Coast Res 7(3):723-744

Grasso M (1997) Carta geologica del settore centro meridionale dell'Altopiano Ibleo (Provincia di Ragusa, Sicilia Sud Orientale). Istituto di Geologia e Geofisica, Università di Catania

Hansom J (2001) Coastal sensitivity to environmental change: a view from the beach. Catena 42(2-4):291-305

Jayappa KS, Kumar GT, Subrahmanya KR (2003) Influence of coastal structures on the beaches of southern Karnataka, India. J Coast Res 19(2):389-408

Jiménez J, Sánchez-Arcilla A, Bou J, Ortiz M (1997) Analysing Shortterm shoreline changes along the Ebro delta (Spain) using aerial photographs. J Coast Res 13(4):1256-1266

Leatherman S (1983) Shoreline mapping: a comparison of techniques. Shore Beach 51:28-33

Lillesand T, Kiefer R (1987) Remote sensing and image interpretation, 2nd edn. Wiley, New York

Lowry P, Carter RWG (1982) Computer simulation and delimitation of littoral drift cells on the south coast of Co. Wexford, Ireland. J Heart Sci R Dublin Soc 4:121-132

Martínez JA, Anfuso G (2008) Spatial approach to medium-term coastal evolution in south Sicily (Italy): implications for coastal erosion management. J Coast Res 24(1):33-42

Masselink G, Pattiaratchi CB (2001) Seasonal changes in beach morphology along the sheltered coastline of Perth, Western Australia. Mar Geol 172:243-263

May JP, Tanner WF (1973) The littoral power gradient and shoreline changes. In: Coates DR (ed) Coastal geomorphology, p 43-61

Moore L (2000) Shoreline mapping techniques. J Coast Res 16 (1):111-124

Pethick J (2001) Coastal management and sea level rise. Catena 42(24):307-322

Phillips M (2007) Beach response to a total exclusion barrage: Cardiff Bay, South Wales, UK. J Coast Res 23(3):794-805

Pilkey O, Dixon K (1996) The Corps and the Shore. Island Press, 272 pp

Pranzini E (2001) Updrift river mouth migration on cuspate deltas: two examples from the coast of Tuscany (Italy). Geomorphology 12:125-132

Rodríguez E, Dean R (2009) A sediment budget analysis and management strategy for fort Piece Inlet, Florida. J Coast Res 25(4):870-883

Zviely D, Klein M (2003) The environmental impact of the Gaza Strip coastal constructions. J Coast Res 19(4):1122-1127 